\title{
ANALISIS PENGARUH TRANSAKSI GADAI EMAS TERHADAP TINGKAT KEUNTUNGAN BANK SYARIAH
}

\author{
Eris Tri Kurniawati \\ Fakultas Ekonomi dan Bisnis Universitas Muhammadiyah Malang \\ E-mail: eris_kurniawati@yahoo.com
}

\begin{abstract}
The basis of this study was to provide a comprehensible description of the gold pawn transaction implemented in sharia banks and would like to identify the effect of the gold pawn transactions toward bank profits. Accordingly, this research applied statistical test instrument, specifically multiple linear regressions and the results revealed that sharia (Rahn) pawn transaction revenue has a positive effect on net income in which the contribution of independent variables on the dependent variable indicated its $R^{2}$ (R-squared)value by $21.08 \%$. Since the independent variable was not the major product which affected the bank's net income, other $78.92 \%$ of net profit variable would be clarified by other variables which were not discussed in this study.
\end{abstract}

Keywords: Pawn Gold, Net Income, Sharia Bank

\begin{abstract}
Abstrak
Penelitian ini bertujuan untuk memberikan deskripsi tentang pelaksanaan transaksi gadai emas di bank syariah dan ingin mengetahui pengaruh transaksi gadai emas tersebut terhadap tingkat keuntungan bank. Untuk menjawab tujuan penelitian ini digunakan alat uji statistik uji regresi linier berganda. Hasil penelitian berdasarkan model regresi menunjukkan bahwa pendapatan transaksi gadai syariah (rahn) memiliki pengaruh positif terhadap variabel laba bersih dimana kontribusi variabel bebas terhadap variabel terikat yang ditunjukkan melalui nilai $R^{2}(R$-squared) adalah sebesar 21,08\%. Mengingat bahwa variabel bebas dalam penelitian ini bukan merupakan produk utama dari bank yang mempengaruhi laba bersih sehingga sisanya sebesar 78,92\% variabel laba bersih akan dijelaskan oleh variabel-variabel yang lain yang tidak dibahas dalam penelitian ini.
\end{abstract}

Kata Kunci: Gadai Emas, Laba Bersih, Bank Syariah

Hadirnya pegadaian sebuah lembaga keuangan formal di Indonesia, yang bertugas menyalurkan pembiayaan dengan bentukpemberian uang pinjaman kepada masyarakat yang membutuhkan berdasarkan hukum gadai merupakan suatu hal yang disambut positif oleh masyarakat. Hadirnya lembaga tersebut diharapkan dapat membantu ma- 
syarakat agar tidak terjerat dalam praktikpraktik lintah darat, ijon dan/atau pelepas uang lainnya.

Sejak keluarnya Undang-Undang Nomor 10 Tahun 1998, perkembangan lembaga perbankan syariah cukup pesat. Demikian pula lembaga keuangan lain, juga sudah membuka unit syariah, di mana salah satu produk layanan yang ditawarkan adalah jasa layanan gadai syariah (rahn). Gadai syariah (rahn) merupakan salah satu alternatif pembiayaan dengan bentuk pemberian uang pinjaman kepada masyarakat yang membutuhkan berdasarkan pada prinsip syariat islam dan terhindar dari praktek riba atau penambahan sejumlah uang atau persentase tertentu dari pokok utang pada waktu membayar utang.

Gadai yang ada saat ini, dalam praktiknya menunjukkan adanya beberapa hal yang dipandang memberatkan dan mengarahkan kepada suatu persoalan riba yang dilarang oleh hukum syara'. Menurut A. A. Basyir, riba'terjadi apabila dalam akad gadai ditemukan bahwa peminjam harus memberi tambahan sejumlah uang atau persentase tertentu dari pokok utang, pada waktu membayar utang atau pada waktu lain yang telah ditentukan penerima gadai. Hal ini lebih sering disebut juga dengan "bunga gadai", yang pembayarannya dilakukan setiap 15 hari sekali. Sebab apabila pembayarannya terlambat sehari saja, maka nasabah harus membayar 2 kali lipat dari kewajibannya, karena perhitungannya sehari sama dengan 15 hari. Hal ini jelas merugikan pihak nasabah, karena ia harus menambahkan sejumlah uang tertentu untuk melunasi hutangnya. Gadai syariah tidak menganut sistem bunga, namun menggunakan biaya jasa (ijarah) sebagai penerimaan dan labanya, yang dengan pengenaan biaya jasa itu, dapat menutupi biaya yang dikeluarkan dalam operasionalnya. Oleh karena itu, untuk menghindari adanya unsur riba' (bunga) dalam gadai syariah dalam usahanya pembentukan laba, maka gadai syariah menggunakan mekanisme yang sesuai dengan prinsip-prinsip syariah, seperti melalui $a k a d$ qardhul hasan dan akad ijarah.

Gadai emas merupakan produk pembiayaan atas dasar jaminan berupa emas dalam bentuk emas perhiasan sebagai salah satu alternatif memperoleh uang tunai dengan cepat, aman dan mudah. Cepat dari pihak nasabah dalam mendapatkan danapinjaman tanpa prosedur yang panjang dibandingkan dengan produk pembiayaan lainnya. Aman dari pihak bank, karena bank memiliki barang jaminan yaitu emas yang bernilai tinggi dan relatif stabil bahkan nilainya cenderung bertambah. Mudah berarti pihak nasabah dapat kembali memiliki emas yang digadaikannya dengan mengembalikan sejumlah uang pinjaman dari bank, sedangkan mudah dari pihak bank yaitu ketika nasabah tidak mampu mengembalikan pinjamannya (utang) maka bank dengan mudah dapat menjualnya dengan harga yang bersaing karena nilai emas yang stabil bahkan bertambah. Faktor kemudahan, kecepatan, dan keamanan atas jasa gadai emas oleh bank syariah inilah yang menjadikan masyakarat tertarik untuk bertransaksi apabila membutuhkan dana dalamjumlahcukup besar.

Ketertarikan masyarakat terhadap gadai emas berpotensi akan memberikan tren peningkatan keuntungan atau laba pada bank syariah. Hal ini diakui oleh direktur Bank Syariah Mandiri, Hanawijaya dalam www.syariahmandiri.co.id yang memberikan informasi bahwa sebagaian besar sumber fee based income adalah berasal dari layanan gadai emas di mana pada akhir tahun 2011 PT. BSM mencatat fee based income sebesar Rp.1.08 triliun, tumbuh $90.94 \%$ 
dibandingkan akhir tahun 2010 senilai Rp. 567 miliar.

Penelitian tentang gadai emas di bank syariah telah banyak dilakukan mengarah pada faktor-faktor yang mempengaruhi minat nasabah berinvestasi di antara penelitian yang dilakukan oleh Gufron (2011) yang menyimpulkan bahwa faktor promosi, prosedur pencairan pinjaman, dan Harga taksiran barang memiliki pengaruh positif dan signifikan pada $\alpha 1 \%$ terhadap Minat nasabah untuk menggunakan Produk Bank Sumut Syariah cabang Medan, di mana faktor Promosi merupakan faktor yang paling utama dalam mempengaruhi minat nasabah untuk menggunakan Produk Qardh dengan Gadai Emas

Transaksi hukum gadai dalam fikih islam disebut ar-rahn. Ar-rahn adalah suatu jenis perjanjian untuk menahan suatu barang sebagai tanggungan hutang.(Rahmat syafi' $i$, 1995: 59). Pengertian "Ar-rahn" dalam bahasa Arab adalah " ats-tsubutwa ad-dawam", yang berarti "tetap" dan "kekal". (Abi Zakariyya ahya bin Syaraf An-Nawawi, 1957: 121). Secara etimologi (Bahasa) kata arrahn berarti: menjadikan sesuatu barang yang bersifat materi sebagai pengingat utang. (Wahbah zuhaily, 2002: 4204).

Dalam Fikih empat mazhab (fikih almadzahib al-arba-ah) di ungkapkan rukun gadai sebagai berikut. 1) Aqid (Orang yang beraqad). Aqid adalah orang yang melakukan akad yang meliputi Dua arah, yaitu (a) Rahin (Orang yang menggadaikan barangnya), dan (b) Murtahin (Orang yang berpiutang dan menerima barang gadai), atau penerima gadai. Hal ini dimaksud didasari oleh Sighat, yaitu ucapan berupa ijab $Q a$ bul (serah terima antara penggadai dan penerima gadai). 2) Ma' qud 'alaih (barang yang di Aqadkan). Dalam hal ini meliputi dua hal, yaitu (a) Marhun (Barang yang digadaikan), dan (b) Marhun bihi (dain), atau utang yang dikarenanya diadakan Aqad rahn. (Abdurrahman Al-jaziri, 1998: 296) namun demikian, ulama fikih berbeda pendapat mengenai masuknya sighat sebagai Rukun dari terjadinya rahn. Ulama mazhab Hanafi berpendapat bahwa sighat tidak termasuk sebagai rukun Rahn, melainkan ijab (pernyataan menyerahkan barang sebagai agunan bagi pemilik barang) dan qabul (pernyatan kesediaan dan memberi utang, dan menerima barang sebagai agunan tersebut). Di samping itu, menurut ulama Hanafi, untuk sementara dan mengikatnya aqad rahn, masih diperlukan apa yang disebut penguasaan barang oleh kreditor ( $A l$-Qabdh), sementara keuangan pihak yang melaksanakan aqad, dan harta yang dijadikan agunan atau jaminan, dalam pandangan ulama Hanafi lebih tepat dimasukkan sebagai syarat rahn bukan rukun rahn. (Zainuddin Ali, 2008: 21). Karena itu, syarat sighat menurut madzhab Hanafi adalah ia tidak boleh dikaitkan dengan persyaratan tertentu, mengikat aqad Rahn sama halnya dengan jual beli.

Pengertian gadai ( $r a h n)$ secara bahasa seperti diungkapkan diatas adalah tetap, kekal, dan jaminan; sedangkan secara terminologi (peristilahan) rahn diartikan sebagai "Menyandera sejumlah harta yang diserahkan sebagai jaminan secara hak, dan dapat diambil kembali harta dimaksud sesudah ditebus" (Zainuddin Ali, 2008: 12), sedang pada pasal 11 ayat 50 Kitab Undang-Undang Hukum Perdata, pengertian gadai dirumuskan sebagai berikut: Gadai adalah suatu hak yang diperoleh kreditor atas suatu barang bergerak, yang diserahkan kepadanya oleh debitor, atau oleh seorang lain atas namanya, dan yang memberikan kekuasaan kepada debitor itu untuk mengambil pelunasan dari barang-barang tersebut secara didahulukan dari pada debi- 
tor-kreditor lainnya; dengan kekecualian biaya untuk melelang barang tersebut dan biaya yang telah dikeluarkan untuk menyelamatkannya setelah barang itu digadaikan, biaya-biaya mana harus didahulukan. (Kartini Muljadi dan Gunawan Widjaya, 2005: 74).

Dari rumusan di atas diketahui bahwa untuk dapat disebut gadai, maka unsur-unsur di bawah ini harus dapat dipenuhi, di antaranya: Gadai diberikan hanya atas benda bergerak, gadai harus dikeluarkan dari penguasaan pemberi gadai, gadai memberikan hak kepada kreditor untuk memperoleh pelunasan terlebih dahulu atas piutang kreditor (droit de preference), gadai memberikan kewenangan kepada kreditor untuk mengambil sendiri pelunasan secara mendahului tersebut.

Berdasarkan pendapat-pendapat di atas, maka disimpulkan bahwa gadai syariah (Rahn) adalah menahan barang jaminan yang bersifat materi milik si peminjam $(R a$ hin) sebagai jaminan atas pinjaman yang diterimanya, dan barang yang diterima tersebut bernilai ekonomis, sehingga pihak yang menahan (Murtahin) memperoleh jaminan untuk mengambil kembali seluruh atau sebagian utangnya dari barang gadai dimaksud.

Bank menerima laba (profit) sebagai penghasilan yang bernilai, dalam arti teknis, laba merupakan kelebihan harga jual barang atau jasa di atas biayanya atau selisih yang timbul pada pendapatan total suatu bisnis lebih besar dari biaya total. Pendapat itu membuat orang menganggap bahwa laba merupakan sisa (residu), karena itulah laba disebut pendapatan residual, adapun maksimalisasi laba ditempatkan sebagai tujuan bisnis dalam teori perusahaan dan teori pasar tradisional. Maksimalisasi laba dapat dijelaskan dalam dua kemungkinan: (1) ketika pendapatan total melebihi pengeluaran to- tal; atau (2) ketika pendapatan marjinal sama dengan biaya marjinal.

Laba merupakan salah satu penggerak perekonomian swasta (private enterprise economy) yang berusaha untuk mengalokasikan sumber-sumber daya di antara pengguna akhir yang saling bersaing dengan permintaan konsumen.

Menurut Komaruddin Sastradipoera (2004:269) laba dapat didefinisikan sebagai berikut:

"Dalam bisnis perbankan, laba adalah jumlah yang tersisa setelah biaya tetap dan biaya variabel dikurangkan dari penerimaan bank; kelebihan pendapatan (income) di atas pengeluaran (expenditure) bank yang dinyatakan dengan rumus:

\section{Y-Ex}

Keterangan:

$\mathrm{Y}=$ Pendapatan

$\mathrm{Ex}=\mathrm{Laba}$

Pendapat Komarudin diatas diperkuat oleh Mudrajad Kuncoro dan Suhardjono (2002:545) dengan pendapat mengenai laba bank. Apabila nilai total pendapatan lebih besar dari pada nilai total biaya untuk kurun waktu yang sama maka bank menghasilkan laba. Sebaliknya apabila total pendapatan lebih kecil dari nilai total biaya maka bank mengalami kerugian. Jadi berdasarkan kedua pendapat tersebut maka dapat diambil kesimpulan yang dimaksud dengan laba dalam penelitian ini merupakan laba bersih.

Berdasarkan definisi laba yang disebutkan sebelumnya dapat disimpulkan bahwa laba memiliki unsur-unsur berupa pendapatan dan biaya. Oleh karena itu untuk mengetahui besarnya laba, manajemen bisnis perbankan perlu memperinci unsur-unsur pendapatan dan unsur-unsur biaya: Unsurunsur pendapatan dalam bisnis perbankan 
biasanya meliputi: 1) Bunga pinjaman yang diperoleh dari nasabah; 2) Kompensasi atas jasa (pelayanan) yang diberikan oleh bank, seperti konsultasi untuk menyusun kajian kelayakan; 3) Laba atas investasi portepel (kumpulan sekuritas yang dimiliki atau atas nama investor;sekuritas). Sedangkan unsurunsur biaya dalam bisnis perbankan biasanya meliputi: 1) Bunga yang dibayar kepada penitipan (deposan); 2) Gaji dan upah personalia bank; 3) Biaya operasional lainnya, seperti biaya kontrak kredit dan biaya inkaso.

Gadai emas yang banyak diminat oleh masyarakat luas merupakan salah satu jasa layanan bank yang berpotensi meningkatkan laba atau tingkat keuntungan bank syariah.

Berdasarkan pembahasan kajian teori dan penelitian terdahulu serta latar belakang permasalahan yang muncul, maka rumusan permasalahan yang diangkat dalam penelitian ini sebagai berikut: Bagaimanakah Pengaruh Transaksi Gadai Emas Terhadap Tingkat Keuntungan Bank Syariah (Studi Kasus Pada PT. Bank Syariah Mandiri Kota Malang)". Sehingga penelitian ini bertujuan untuk (1) Memberikan gambaran tentang pelaksanan layanan gadai emas di PT. Bank Syariah Mandiri Kota Malang (2) Mengetahui pengaruh transaksi gadai emas terhadap tingkat keuntungan PT. Bank Syariah Mandiri Kota Malang.

\section{Metode Penelitian}

Penelitan ini merupakan penelitian studi kasus dengan menggunakan metode deskriptif kuantitatif yaitu suatu bentuk penelitian yang berdasarkan data yang dikumpulkan selama penelitian secara sistematis mengenai fakta-fakta dan sifat-sifat dari objek yang diteliti menggabungkan hubungan antar variabel yang terlihat di dalamnya, kemudian diinterpretasikan berdasarkan teori-teori dan literatur-literatur yang berhubungan, di mana data tersebut akan dihitung secara statistik dengan tujuan untuk menguji hipotesis yang ada (Nazir, 2003:71).

Berdasarkan aspek yang diteliti dalam penelitian maka terdapat dua variabel mendasar terdiri dari variabel Y (dependent variable) dalam penelitian ini adalah tingkat keuntungan (laba) atau profit, didefinisikan sebagai jumlah yang tersisa setelah biaya tetap dan biaya variabel dikurangkan dari penerimaan bank.

Sedangkan variabel independen (X) adalah pendapatan ijarah yang diterima oleh Bank atas layanan jasa gadai emas (rahn), merupakan produk pembiayaan atas dasar jaminan berupa emas dalam bentuk emas perhiasan sebagai salah satu alternatif memperoleh uang tunai dengan cepat, aman dan mudah.

Jenis dan sumber data yang dibutuhkan untuk menunjang penelitian ini adalah data sekunder dan data primer. Data sekunder merupakan data yang telah ada dan tersusun secara sistematis serta merupakan hasil penelitan atau rangkuman dari dokumen-dokumen perusahaan serta literature, laporan keuangan tahunan, buku, majalah, surat kabar, makalah, dan situs web. Data primer diperoleh untuk memberikan gambaran tentang mekanisme pelaksanan transaksigadai (rahn) produk emas melalui teknik observasi dan wawancara.

Teknik pengumpulan data menggunakan penelitian kepustakaan (Library Research) yaitu mencari data sekunder yang diperoleh dari berbagai sumber, baik dari literature, artikel, data perusahaan, dan lainlain yang dianggap relevan dengan penelitian. Tujuan penelitian kepustakaan ini adalah untuk memperoleh data teoritis untuk membangun landasan teori yang kuat guna men- 
dukung penelitian ini. Penelitian Lapangan (Field Research) juga merupakan teknik pengumpulan data dalam penelitian ini, yaitu teknik untuk memperoleh data secara akurat baik melalui survei langsung atau wawancara ke perusahaan yang menjadi objek penelitian.

Metode kualitatif, mengemukakan datadata yang didapat dengan mengelompokkan, mentabulasi, dan memberikan penjelasan.

Proses analisa didasarkan pada analisis deskripif berdasarkan wawancara dan observasi langung. Pelaksanaan meliputi pengumpulan data, penyusunan data, interpretasi tentang makna data tersebut.

Metode kuantitatif, dilakukan dengan alat bantu statistik yaitu menggunakan program SPSS (Statistical Product and Service Solutions) untuk menyelesaikan uji regresi linier yang telah terbentuk guna melihat pengaruh variabel bebas (pendapatan ijarah) terhadap variabel terikat (tingkat keuntungan bank) dan uji hipotesis.

Dalam penelitian ini digunakan beberapa alat uji analisis sebagai pendukung dalam penelitian ini untuk mendapatkan hasil penelitian yang diharapkan. Berikut merupakan beberapa alat analisis yang digunakan dalam penelitian ini:

Uji validitas dan realibilitas, Pengujian ini dilakukan dengan tujuan untuk mengetahui apakah data yang dihasilkan dari alat ukur tersebut dapat menjamin mutu dari penelitian sehingga kesimpulan ataupun alasanalasan yang dikemukakan terhadap hubungan antar variabel dapat dipercaya, akurat, dan dapat diandalkan agar pada akhirnya hasil penelitian bisa diterima. Selain itu, penulis juga tidak mengambil kesimpulan yang keliru mengenai gambaran keadaan yang sebenarnya terjadi. Pengujian validitas dan reliabilitas ini dilakukan dengan meng- gunakan program SPSS (Statistical Product and Service Solutions).

Uji regresi berganda, yaitu untuk menganalisis tingkat pengaruh variabel bebas (X) yatu pendapatan ijarah terhadap variabel terikat (Y) yaitu keuntungan bank maka dibentuk model analisis yang menggunakan model regresi linier berganda. Model penelitian ini diestimasidengan menggunakan metode OLS (Ordinary Least Square).

\section{Hasil Penelitian dan Pembahasan}

Dalam mengukur besarnya pengaruh gadai emas yang diinterpretasikan dengan Fee Rahn $\left(\mathrm{X}_{1}\right)$ terhadap laba bersih $(\mathrm{Y})$ dilakukan dengan alat regresi linier sederhana dalam bentuk log, adapun model hasil analisis dapat diinterpretasinya sebagi berikut:

$$
\begin{aligned}
& \mathrm{LY}=\beta_{0}+\beta_{1} \mathrm{LX}_{1}+\varepsilon_{\mathrm{t}} \\
& \mathrm{LY}=15,01+0,27 \mathrm{LX}_{1}
\end{aligned}
$$

Nilai $\beta_{0}$ sebesar 15,01 berarti laba bersih $(\log Y)$ sebesar 15,01 pada saat Fee Rahn $\left(\log X_{1}\right)$ sama dengan atau dianggap nol (konstan). Sedangkan nilai $\beta_{1}$ sebesar koefisien regresi variabel Fee Rahn (Log $\mathrm{X}_{1}$ ) sebesar 0,27 berarti ada pengaruh positif antara Fee Rahn terhadap laba bersih sebesar 0, 27. Apabila Fee Rahn $\left(\log X_{1}\right)$ naik sebesar $1 \%$ maka laba bersih $(\log Y)$ akan mengalami peningkatan sebesar 0,27. Sebaliknya apabila Fee Rahn $\left(\log X_{1}\right)$ turun sebesar 1\% maka laba bersih $(\log \mathrm{Y})$ akan turun sebesar 0,27.

Dari hasil regresi di atas dapat disimpulkan bahwa Fee Rahn $\left(\mathrm{X}_{1}\right)$ berpengaruh positif terhadap variabel terkait (laba bersih).

Hasil Uji t test menunjukan hasil t test antara $\mathrm{X}_{1}$ (Fee Rahn) dengan Y (laba bersih) menunjukkan t hitung $=2,969$ Sedangkan $\mathrm{t}$ tabel $(\alpha=0,05 ; \mathrm{db}$ residual $=35)$ adalah sebesar 2,030. Karena thitung $>\mathrm{t}$ tabel 
yaitu 2,969> 2,030 maka pengaruh $\mathrm{X}_{1}$ (Fee Rahn) adalah signifikan pada tingkat kesalahan $\alpha=5 \%$. Hal ini berarti $\mathrm{H}_{0}$ ditolak dan $\mathrm{H}_{1}$ diterima, sehingga dapat disimpulkan bahwa laba bersih dapat dipengaruhi secara signifikan oleh Fee Rahn.

Koefisien determinasi digunakan untuk melihat kontribusi variabel bebas terhadap variabel terikat. Koefisien determinasi $\left(\mathrm{R}^{2}\right)$ maupun koefisien determinasi yang disesuaikan menunjukkan variabel penjelas dalam menjelaskan variasi variabel terikat. Jika nilai $\mathrm{R}^{2}$ semakin mendekati 1 maka dapat dinyatakan model semakin baik dengan asumsi tidak terjadi regresi lancung. Dari analisa perhitungan diperoleh nilai $\mathrm{R}^{2}(\mathrm{R}-$ squared) seperti dalam tabel 1 .

Berdasarkan Tabel 1, didapatkan koefisien determinasi $\mathrm{R}^{2}$ sebesar 0,2108 Artinya bahwa 21,08\% variabel laba bersih akan dijelaskan oleh variabel bebasnya, yaitu Fee Rahn $\left(\mathrm{X}_{1}\right)$. Sedangkan sisanya sebesar 78,92\% variabel laba bersih akan dijelaskan oleh variabel-variabel yang lain yang tidak dibahas dalam penelitian ini.

Uji ini dilakukan untuk mengetahui apakah nilai residual tersebar normal atau tidak. gangguan, ei yaitu dengan menggunakan Jarque-Bera test dengan ketentuan:

a. Jika Jarque-Bera ${ }_{\text {stat }}>X_{\text {tabel }}^{2}$, residual $e i$ tidak berdistribusi normal.

b. Jika Jarque-Bera ${ }_{\text {stat }}<$ tabel , residual berdistribusi normal.

Hasil nilai Jarque-Bera ${ }_{\text {stat }}$ adalah 3,7178 dan nilai tabel diperoleh dengan $=$ $5 \%$ dan d.f $=1$ sebesar 3,8415. Sehingga Jarque-Bera $_{\text {stat }}$ lebih kecil dari ${ }_{\text {tabel}}$, yang dapat disimpulkan bahwa model yang digunakan mempunyai residual atau faktor pengganggu berdistribusinormal atau model lolos normalitas.

Beberapa metode untuk menguji ada tidaknya heteroskedastisitas dalam variabel error term pada suatu model regresi yaitu menggunakan White Test. Adapun hasil uji White menunjukkan bahwa nilai Chi Square

Tabel 1. Hasil Estimasi Persamaan

Dependent Variable: LLABA

Method: Least Squares

Date: 03/21/13 Time: 21:21

Sample: 2010M01 2012M11

Included observations: 35

\begin{tabular}{ccccr}
\hline Variable & Coefficient & Std. Error & t-Statistic & Prob. \\
C & 15.01357 & 1.438998 & 10.43335 & 0.0000 \\
LFEE & 0.268221 & 0.090342 & 2.968956 & 0.0055
\end{tabular}

R-squared

Adjusted R-squared

S.E. of regression

Sum squared resid

Log likelihood

F-statistic

Prob(F-statistic)
0.210804 Mean dependent var

19.26960

0.186889 S.D. dependent var

0.823650

0.742707 Akaike info criterion

2.298415

18.20324 Schwarz criterion

2.387292

-38.22225 Hannan-Quinn criter.

2.329095

8.814698 Durbin-Watson stat

0.544863

0.005530 
hitung sebesar 1,21 (diperoleh dari Obs*Rsquared), sedangkan nilai kritis chi squares $\left(\mathrm{X}^{2}\right)$ pada $=5 \%$ dengan df sebesar 1 adalah 3,8415. Karena nilai chi squares hitung $\left(\mathrm{X}^{2}\right)$ lebih kecil dari nilai kritis chi squares $\left(\mathrm{X}^{2}\right)$ maka dapat disimpulkan tidak ada masalah heteroskedastisitas.

Pencapaian pendapatan berbasis biaya (fee based income) oleh PT Bank Syariah Mandiri (BSM) yang bersumber salah satunya dari fee rahn atas transaksi gadai emas, dibuktikan melalui hasil penelitian ini memiliki pengaruh positif dan signifikan terhadap kenaikan laba bersih BSM secarakeseluruhan, meskipun kontribusinya hanya sebesar $21,08 \%$. Kontribusi penyumbang laba perseroan yang berasal dari fee rahn ini memang tidak besar karena bukan merupakan pendapatan dari core finance pro$d u c t$, seperti keuntungan yang berasal dari produk-produk pembiayaan utama bank syariah yang dapat berupa pendapatan margin dan bagi hasil.

Hal inijuga dijelaskan melalui SuratEdaran Bank Indonesia dalam prinsip kehatihatian dalam penerapan produk Qord beragunan Emas yang dijelaskan bahwa jumlah portofolio Qord beragunan Emas pada setiap akhir bulan paling banyak: 1) Untuk Bank Syariah, jumlah yang lebih kecil antara $20 \%$ dari jumlah seluruh pembiayaan yang diberikan atau sebesar $150 \%$ dari modal bank sebagaimana dimaksud dalam ketentuan BI yang mengatur mengenai Kewajiban Penyediaan Modal Minimum (KPPM); 2) Untuk UUS, sebesar $20 \%$ dari jumlah seluruh pembiayaan yang diberikan; 3) Pembiayaan Qord beragunan emas dapat diberikan paling banyak Rp.250.000.000,untuk setiap nasabah, dengan jangka waktu 4 bulan dan dapat diperpanjang 2 (dua) kali;

4) Khusus untuk nasabah usaha mikro dan kecil, dapat diberikan pembiayaan qord beragunan emas paling banyak sebesar Rp. 50.000.000,- dengan jangka waktu pembiayaan paling lama 1 (satu) tahun dengan angsuran setiap bulan dan tidak dapat diperpanjang; 5) Finance to value (FTV) yang merupakan perbandingan antara jumlah pinjaman yang diterima oleh nasabah dengan nilai emas yang diaunkan oleh nasabah kepada Bank Syariah atau UUS, paling banyak adalah sebesar $80 \%$ dari rata-rata harga jual emas 100 gram dan harga beli kembali (buyback) emas PT. Antam Persero Tbk.

Dengan adanya regulasi dari BI untuk transaksi gadai emas tersebut makafee $b a$ sed income yang bersumber dari transaksi tersebut secara tidak langsung terbatasi meskipun bisnis gadai emas di perbankan syariah kini tengah menjadi primadona. Namun, di sisi lain, yang perlu dicermati bahwa gadai emas menjadi bahan kritikan karena fungsi intermediasi lembaga perbankan syariah dinilai menjadi kurang maksimal karena rentan dijadikan ajang para spekulan untuk mencari keuntungan yang sebesar-besarnya. Olehkarena itu dibutuhkan penyempurnaan dari BI dalam mengelola risiko gadai emas.

\section{Penutup}

Berdasarkan hasil dan pembahasan penelitian yang dikemukakan di atas, maka dapat disimpulkan bahwa: Terdapat pengaruh positif signifikan antara fee rahn terhadap laba bersih perseroan Bank Syariah Mandiri Tbk.

Implikasi dari penelitian ini diharapkan dapat menjelaskan kepada masyarakat bahwa fee based income Bank Syariah Mandiri yang bersumber dari transaksi gadai emas memberikan kontribusi yang positif signifikan pada laba bersih perseroan secara keseluruhan. Masyarakat dapat menjadikan 
Analisis Pengaruh Transaksi Gadai Emas.... (Eris Tri Kurniawati)

transaksi Gadai syariah (rahn) sebagai salah satu alternatif pembiayaan dengan bentuk pemberian uang pinjaman berdasarkan pada prinsip syariat islam dan terhindar dari praktek riba.

Melalui gambaran pelaksanaan proses transaksi gadai syariah, diharapkan pengenalan atau sosialiasi tentang akad yang digunakan dalam transaksi gadai emas di bank syariah dalam hal ini adalah akad qardh wal ijarah dapat tersampaikan, di mana dalam akad ini merupakan akad pemberian pembiayaan dari bank untuk nasabah yang disertai dengan penyerahan tugas agar Bank menjaga barang jaminan yang diserahkan. Di mana dalam al-Qur an surat al-Baqarah ayat 283 dijelaskan bahwa gadai pada hakikatnya merupakan salah satu bentuk dari konsep muamalah, di mana sikap menolong dan sikap amanah sangat ditonjolkan.

\section{DAFTAR PUSTAKA}

Budisantoso, Totok dan Sigit Triandaru. 2006. Bank dan Lembaga Keuangan Lain (Edisi Kedua). Salemba Empat. Jakarta.

Kasmir. 2003. Manajemen Perbankan. Raja Grapindo Persada. Jakarta.

Kuncoro, Mudrajaddan Suhardjono. 2002. Manajemen Perbankan: Teori dan Aplikasi. BPFE. Yogyakarta.

Nazir, Moh. 1999. Metode Penelitian. Ghalia. Jakarta.

Rinaldy, Eddie. 2008. Membaca Neraca Bank. Indonesia Legal Center Publishing. Jakarta.

Sastradipoera, Komarudin. 2004. Strategi Manajemen Bisnis Perbankan,
Konsep dan Implementasi untuk Bersaing. Kappa-Sigma. Bandung.

Siamat, Dahlan. 2004. Manajemen Lembaga Keuangan (Edisi Keempat). Lembaga Penerbit Fakultas Ekonomi Universitas Indonesia. Jakarta.

Sinungan, Muchdarsyah. 2000. Manajemen Dana Bank (Edisi kedua). Bumi Aksara. Jakarta.

Sugiarto, Agus. 2004. Mencari Struktur Perbankan Yang Ideal. Bank Indonesia. Jakarta. 
